911.3

\author{
- \\ ьвівський н ціон льний університет імені в н \\ вул. . орошенк , 41, м. ввів, 79000, кр їн
}

озкрито сутність поняття вибори президент кр їни. роблено н ліз відмінностей регіонів кр їни під впливом різних чинників. ідобр жено особливості виборів 2010 р. н тлі інших виборів. изн чено вплив лицького регіону н результ ти виборів $2010 \mathrm{p}$.

лючові слов : ибори президент, личин, електор льн поведінк, результ ти виборів, н ціон льно-демокр тичний к ндид т.

ибори є н йбільш суттєвим проявом демокр тії, з г льним критерієм зрілості, цивілізов ності т цілісності суспільств . ибори - це невід'ємний процес, який відбув ється в кожній держ ві. ибори можуть слугув ти своєрідним індик тором ступеня демокр тичності тієї чи іншої кр їни. мерик нський філософ ж. ьюї н голосив, що політичн демокр тія 6 г то в чому формується як теорія і пр ктик політичних виборів [3, с. 61]. пр вді, уч сть більшості гром дян у вл ді т процедурне з безпечення цієї уч сті є головною умовою демокр тії. $\quad$ г льне, рівне, вільне, пряме, т ємне виборче пр во є основою демокр тії як політичного режиму. ме вибори перетворюють волевиявлення гром дян н волю н роду, з безпечують добір політичної еліти, зумовлюють суспільно-політичний курс кр їни [9, с. 9].

кр їні вибори президент відбув лися чотири р зи. м йже н кожних вибор х простежув вся - чіткий регіон льний розподіл виборців 3 “свого” к ндид т . ому сьогодні досить кту льним є політико-геогр фічний н ліз електор льної ктивності н селення.

зн чимо, що тему виборів широко обговорюють і досліджують у н укових кол х. окрем , ост нніми рок ми опубліков но зн чну кількість ст тей і моногр фій з особливостей поведінки виборців кр їни. г тьом спект м цього н пряму політикогеогр фічних досліджень присвячені н укові пр ці . гров , . олод , . ністрянського, . иронюк, . опчієв , . н , . блія, . иш цького. крім геогр фів, пит ння електор льної поведінки н селення висвітлюють політологи . тенко, . ерг чов, . ед нь, . дісон, . ремінь, . оменко, . хов, . ведов. успільно-геогр фічні пр ці присвячені проблем тиці геопросторових спектів виборчого процесу, н лізу чинників, що визн чили електор льну поведінку т виборчу ктивність н селення певних територій [8]. иповою особливістю більшості вітчизняних досліджень виборів є пр гнення охопити всю територію держ ви, як н слідок, невисвітлен ситу ція електор льної поведінки з регіон ми кр їни. ому н ш мет - висвітлити електор льну поведінку одного історичного регіону кр їни. сі інші регіони розглянемо через призму суспільно-геогр фічних особливостей, які вплив ють н їхню електор льну поведінку.

(С) льч К 
сновною джерельною б зою будуть офіційні результ ти ентрвиборчкому. оловн н ш мет висвітлення впливу лицького регіону н результ ти виборів резидент кр їни 2010 р. ля цього зіст вимо співвідношення голосув ння в першому т другому тур х виборів 2010 р., т кож порівняємо результ ти виборів 2010 р. $з$ результ т ми попередніх виборів.

кр їні президент обир ють через кожні п’ять років н з с д х усен родного волевиявлення. резидентом кр їни може бути тільки гром дянин кр їни, який досяг 35-ти річного віку, м є пр во голосу, прожив є в кр їні протягом десяти ост нніх років перед вибор ми і володіє держ вною мовою. резидент не може перебув ти н посту гл ви держ ви більше двох термінів підряд. орядок проведення виборів перед6 чений з коном.

ід ч су здобуття кр їною нез лежності 24 серпня 1991 р. вибори відбув лися чотири р зи, не вр ховуючи президентську к мп нію 2010 р. ибори в кр їні з вжди проходять в умов х політичної н пруженості. ожен з м крорегіонів, як з свідчує досвід попередніх президентських виборів, голосує пр ктично одн ково. бл сті хідної кр їни підтримують н ціон л-демокр тів, східні т південні - лібер л-космополітів, центр льні регіони відд ють більшу перев гу н ціон л-демокр т м. ьому сприяе т к низк чинників т особливостей кожного регіону.

1. сторичне перебув ння регіонів кр їни у скл ді інших держ в. прикл д, трив ле перебув ння личини в скл ді встро- горщини зумовило існув ння тут широкого спектр політичних т гром дсько-політичних орг ніз цій, що сприяло формув нню певного рівня розвитку демокр тії т політичної культури н селення і привело до появи елементів інституціон льної виборчої інфр структури [6]. е ст ло однією 3 причин того, шо н селення личини підтримує н ціон льно-демокр тичну ідеологію. ому регіон в умов х нез лежної кр їни в геополітичних стр тегіях пр гне бути 3 європейськими держ в ми, з якими б чить своє м йбутнє, і н вибор х голосує 3 к ндид $\mathrm{T}$, який ув ж є головним вектором зовнішньої політики вропейський простір.

томість хідн т івденн кр їн перебув л під вл дою тільки осії т де демокр тичних тр дицій не було, н томість п нув л політик русифік ції. огляду н це укр їнське н селення тут м $€$ зн чно нижчий рівень с мосвідомості, ніж у личині, тому н вибор х голосує 3 проросійського к ндид т , бо б чить у ньому президент , який зблизить кр їну з осією, тобто визн чить геополітичну стр тегію, як буде орієнтув тися не н 3 хід, н схід.

2. тнон ціон льний т мовний чинник т кож сприяє поділу кр їни т визн ч є електор льну поляриз цію н селення. прикл д, з ост ннім переписом н селення 2001 р. в кр їні прожив ло пон д 77,8 \% укр їнців, пон д $17 \%$ росіян, $3 \%$ предст вників інших н ціон льностей. йбільш ч стк укр їнців прожив є в хідній кр їні, особливо в личині, - пон д $94 \%$, де етнічно укр їнське н селення н вибор х голосує 3 н ціон льно-демокр тичного к ндид т , який сповідує н ціон льно-демокр тичні ідеї - ідеї єдиного гром дянств , однієї держ вної мови. томість у хідній т івденній кр їні, де у скл ді регіонів є висок ч стк росіян, пок зник етнічно укp їнського н селення ст новить $70 \%$, ще менший він у онецькій обл. $(56,9 \%)$ т риму $(4,3 \%)$. відси - величезн популярність ідей союзу з осією, подвійного гром дянств , н д ння російській мові ст тусу держ вної [2, с. 371]. ому зн чний етнічно російський електор т цих регіонів голосує з проросійського к ндид т , який ст вить ці ідеї як основні в своїй передвиборчій прогр мі. 
кі ж тенденції і в мовній структурі. йбільше укр їнською мовою розмовляють н ході, н йменше - н ході т івдні, що т кож визн ч $є$ поділ електор ту н хід, який голосує з н ціон льно-демокр тичні сили, т хід, який мент льно поєдн ний $з$ осією і голосує 3 проросійські сили.

3. елігійний чинник. елігійно-геогр фічн ситу ція в кр їні, як етнон ціон льн , і мовн , теж неоднорідн . $\quad 3$ ході, особливо в личині, перев ж ють прихильники i ( ), які з вжди були н дійним оплотом збереження і розвитку н ціон льних озн к, н ціон льної ідеї. томість н ході т івдні перев ж ють прихильники ( ), як є могутнім з собом русифік ції всього ходу і івдня кр їни, що сприяє поширенню тут москвофільської орієнт ції.

4. оці льно-економічний чинник т кож в гомий, оскільки й тут є поділ головно н індустрі льний схід т перев жно гр рний з хід. східних регіон х нем є тр диції, як створює певну ст більну орієнт цію. о того ж, цей індустрі льний регіон з зн в н йбільших м тері льних втр т від руйнув ння, пов'яз ного з невд лими економічними перетвореннями. Г то підприємств було розформов но. свідомості людей цього регіону сформув вся т кий стереотип: індустрі льні регіони пр цюють, інш ч стин кр їни спожив є. вичні до мігр ції г лич ни пр цюють 3 кордоном, н томість донечч ни т кої рухливості не виявляють. них з вжди було нез доволення м тері льним ст ном, н першому пл ні - перев жно соці льні пит ння, тоді як н північному-з ході сприйм ли це через призму н ціон льних проблем [5, с. 6].

сі перелічені ф кти є головними рушіями, які сприяють тому, що в кр їні вибори ч сто відбув ються в умов х політичної н пруженості, ф льсифік цій, з використ нням дмінресурсу. ожемо лише зг д ти вибори 2004 р., які супроводжув лися м совими ф льсифік ціями т ст ли причиною ом р нчевої революції.

ибори 2010 р, як і попередні, відбулися у дв тури. ля проведення виборів президент в кр їні було створено 225 територі льних виборчих округів. д ними , н поч ток голосув ння до уточненого списку виборців було внесено 36578590 гром дян кр їни, які досягли 18-річного віку, н з кордонних виборчих дільницях 415105 виборців. од ли з явки про голосув ння вдом 568738 осіб, що ст новить трохи більше $3 \%$ виборців. олосув ння з безпечув ли пон д 808 членів виборчих комісій. “президентське крісло” зм г лися 18 к ндид тів, 49 претендент м було відмовлено в реєстр ції.

езв ж ючи н зн чні труднощі, які перешкодж ли проведенню виборів, зокрем , погодно-клім тичні умови т неточності в списк х виборців, т кож н явність у списК х т к зв них мертвих душ, вибори все ж т ки відбулися. роте, явк виборців бул н йменшою з всі ч си нез лежності кр їни - тільки 66,76\%, бо 24588257 осіб.

же тр диційно, що н йбільш ктивно голосув л личин : у ьвівській, в нор нківській т ернопільській обл стях - 73,7, 70,5, т 73,1 \% голосів, відповідно. роте, якщо порівняти явку виборців 2010 р. з 2004 р. то поб чимо, що мешк нці хідної кр їни з г лом і г лицькі обл сті зокрем, проголосув ли менш ктивно, ніж 3 звич й. е ст ло причиною того, що ч стк г лицького електор ту в з г льній структурі голосів по кр їні дещо знизил сь, це, без сумніву, погіршило кінцевий підсумок. еред г лицьких обл стей особливо низьку явку м л в но- р нківщин , яку з відсотком проголосов них обійшл уг нщин, чого р ніше не спостеріг ли н вибо$\mathrm{p}$ X.

вибор х у першому турі г лич ни проголосув ли з н ціон льно-демокр тичних к ндид тів, яких було досить 6 г то. еред виборцями пост ло непросте 3 вд ння, 3 
кого голосув ти - 3 . щенк, ще чинного резидент, ле з незн чним рейтингом в кр їні, чи з . имошенко, як м л зн чно більшу підтримку укр їнців і ре льно претендув л н крісло президент, молодого мбітного . ценюк чи н ціон ліст . ягнибок . решті-решт голосув ння з свідчило, що с ме ці к ндид ти н бр ли н йбільшу кількість голосів у личині. роте, т к розпорошеність електор ту виборців н різних к ндид тів нег тивно вплинул н підсумковий результ т першого туру. мість того, щоб н ціон льно-демокр тичні сили об'єдн лися і висунули єдиного к ндид $\mathrm{T}$, вони пішли кожен з себе, що й ст ло причиною їхньої пор зки.

ерший тур виборів довів, в кр їні відбулися чесні, прозорі т демокр тичні вибори, що і підтвердили іноземні спостеріг чі.

о другого туру пройшли дв к ндид ти - лідер ртії регіонів . нукович, який переміг у першому турі, н бр вши 35,32 \% голосів, т лідер . имошенко, як посіл друге місце з результ том 25,05\%.

кщо результ ти першого туру президентських виборів були більш-менш очікув ними, чим 3 кінчиться другий тур, не хотіли прогнозув ти н віть вторитетні експерти.

г то 3 них з зн ч ло про м сові ф льсифік ції, зрив виборів н дільницях тощо. редст вники обох к ндид тів говорили про можливі післявиборні “революціі” з боку протилежних т борів [1, с. 8] .

другому турі виборів президент кр їни 2010 р. кількість виборців, які взяли уч сть у голосув нні, ст новил $69,15 \%$, що н 2,35\% більше, ніж під ч с першого туру 17 січня, коли явк ст новил $66,76 \%$. к підтвердил ся тенденція: явк у виріш льному турі виборів президент порівняно з першим туром зрост є. опри те, 7 лютого з фіксов но н йнижчу, порівняно з іншими повторними голосув ннями н президентських вибор х в історії кр їни, кількість гром дян, які прийшли н виборчі дільниці. окрем , н другий тур виборів президент 1994 р. прийшло 71,4 \% виборців, 1999 - 74,9, 2004 - 77,1, 2010 р. - 69,15\% [11].

йбільше зрост ння явки виборців з фіксов не у онецькій обл. (н 7,3\%) т в риму (н $6 \%$ ). е ст ло одним із чинників перемоги лідер регіон лів. личин, iнше електор льне “поле" з тр диційно високою явкою, т кож продемонструв л непог ну ктивність порівняно з першим туром виборів. ернопільській обл. проголосув ло н йбільше виборців по кр їні $-77,8 \%$ (+ 4,7\% порівняно 317 січня). оволі суттєво зросл явк і в в но- р нківській обл. (н $4 \%$ ), у ьвівській - тільки н 1,6\%.

же звично, що личин н вибор х відд л більшість голосів 3 н ціон льнодемокр тичного к ндид т, н против гу проросійському. дн к порівняно з минулими вибор ми відсоток голосів $з$ лідер в личині був помітно меншим (т бл. 1.).

ідсоток виборців з лідер в личині з 1994-2010 pp.

блиця 1

\begin{tabular}{|c|c|c|c|c|}
\hline \multirow[b]{2}{*}{ бл сть } & \multicolumn{4}{|c|}{ оКИ } \\
\hline & $\begin{array}{l}1994 \\
(. \quad \mathrm{p} \text { вчук) }\end{array}$ & $\begin{array}{c}1999 \\
\left(\begin{array}{c}\text { учм } \\
\text { ( }\end{array}\right)\end{array}$ & $\begin{array}{ll} & 2004 \\
(. & \text { щенко) }\end{array}$ & $\begin{array}{c}2010 \\
(\text {. . имошенко) }\end{array}$ \\
\hline ьвівськ & 93,77 & 91,59 & 93,74 & 86,2 \\
\hline ернопільськ & 94,8 & 92,17 & 96,03 & 88,39 \\
\hline в но- $p$ нківськ & 94,46 & 92,3 & 95,72 & 88,9 \\
\hline
\end{tabular}

жерело: [11]. 
чевидно, зменшення ктивності виборців у личині, досягнуто з вдяки з клик м

щенк т . ценюк не підтримув ти в другому турі жодного к ндид т ; одн к відсоток “проти обох" у личині, хоч й був досить високим і н 2-3\% зріс порівняно з 2004 р., все жз лишився помітно нижчим, ніж у середньому по кр їні (т бл. 2.).

блиця 2

олосув ння проти обох к ндид тів

\begin{tabular}{|c|c|c|c|}
\hline \multirow{2}{*}{ бл сть } & \multicolumn{3}{|c|}{ оки } \\
\cline { 2 - 4 } & 1999 & 2004 & 2010 \\
\hline ьвівськ & 1,44 & 0,77 & 4,15 \\
\hline ернопільськ & 1,47 & 0,54 & 2,83 \\
\hline в но- р нківськ & 1,33 & 0,55 & 2,84 \\
\hline о кр іні & 3,44 & 2,34 & 4,36 \\
\hline
\end{tabular}

жерело: [11].

н слідок нижчої ктивності виборців 3 . имошенко в трьох г лицьких обл стях проголосув ли н 587 тис. виборців менше, ніж з . щенк під ч с ом р нчевої революції. дн к пробудження н ціон л-демокр тичного електор ту до рівня 2004 р. н вряд чи було б можливим 3 т кої політичної ситу ції в кр їні. ожн стверджув ти, що н цих вибор х . имошенко з г лом викон л з вд ння ефективної мобілі3 ції “проти” в тих регіон х, де іï результ т у першому турі був не досить зн чним, проте в яких лідер регіон лів м в н йбільший нтирейтинг.

иборці . щенк , який здобув основну ч стину своїх голосів у личині, підтрим ли в другому турі . имошенко, ле не повною мірою. реб т кож звернути ув гу н т ку особливість, як результ т виборів у місті ьвові, де в першому турі переміг лідер “ шої кр їни”, у другому турі підтримк . нукович зросл вдвічі - з 8,5 до м йже $15 \%$ з $7 \%$ проти обох к ндид тів [11].

дн к, незв ж ючи н ці пок зники зрост ння рейтингу . нукович в личині між першим т другим тур ми виявилося не досить зн чним. прикл д, у ьвівській обл. він н бр в 8,6 \% голосів (н 2,93 \% і 47 тис. голосів більше, ніж у першому турі).

в но- р нківщині з . нукович проголосув ло н йменше виборців по кр їні7,02\% (+ 1,91\% і 18 тис. виборців порівняно з першим туром).

йбільшою несподів нкою виявився результ т у другому турі в ернопільській обл., де нукович отрим в н 5 тис. голосів менше, ніж у першому турі. обто відсоток голосів знизився з 10 до 7,92\%. т бл. 1 б чимо, що н йбільший відсоток відд них голосів 3 . имошенко з безпечил в но- p нівськ, дещо менше - ернопільськ т ьвівськ обл сті.

к б чимо, що у трьох лицьких обл стях підтримк . нукович у відсотк х н йменш по кр їні. томість зн чн підтримк у східних т південних обл стях, ч стк яких ст новить від $70 \%$ у икол ївській до $90 \%$ у онецькій обл. обто результ ти, відобр жені н рис. 2 і 3, з свідчують, що н йбільшу підтримку н ціон льнодемокр тичного к ндид т . имошенко з безпечили обл сті івнічно- хідної кp їни з н йбільшим осередком підтримки в личині. томість 3 проросійського к ндид т відд ли свої голоси обл сті івденного- ходу кр їни з н йбільшою підтримкою в онб сі. 
г лом кількість виборців, які взяли уч сть у другому турі виборів, по кр їні ст новил 25493503 осіб. гідно з протоколом ․ . нукович підтрим ло 48,95\% виборців, . имошенко 45,47\%. бсолютних цифр х 3 лідер ртії регіонів проголосув ло 12481266 виборців, з . имошенко - 11593 357. тже, згідно з протокол ми , розрив між двом к ндид т ми ст новить 3,48\% голосів бо 887909 голосів в бсолютних зн ченнях. е підтрим ли жодного к ндид т 111351 виборець. изн но недійсними 1,19\% виборчих бюлетенів [12].

. имошенко перемогл в 17 дміністр тивно-територі льних одиницях кр їни, тоді як - нукович, якого центр льн виборч комісія оголосил резидентом кp їни, переміг лише у 10 регіон х, вісім з яких у хідній кр їні н йбільш густон селені. . имошенко, перемігши у 17 регіон х, усе ж т ки поступил ся • нуковичу через меншу кількість н селення в дміністр тивних одиницях. обл стях личини кількість голосів, які були відд ні з имошенко, ст новил 3025941 осіб, бо $26 \%$ усіх под них голосів по кр їні. томість якщо взяти дві обл сті хідної кр їни онецьку і ніпропетровську - у яких зн чно менший відсоток, (особливо це стосується ніпропетровської обл.), ч стк виборців, які відд ли свій голос 3 . нукович , ст новить 4533497 осіб, тобто пон д $36 \%$ усіх голосів з теперішнього президент .

ожн говорити про те, що дві обл сті онб су д ли 36 \% голосів нині чинному резиденту, тоді як три обл сті личини - тільки $26 \%$. і д ні з свідчують т ке: якби президентом кр їни ст л лідер - имошенко, то вплив г лицьких обл стей н результ ти виборів був би досить зн чним і ст новив четверту ч стину всіх голосів, 3 умови збільшення відсотк голосув ння цей пок зник міг би збільшитися до $30 \%$. ому личин , як 17 березня 1991 р. н референдумі ст л єдиним регіоном кр їни, який к тегорично виступив 3 нез лежність кр їни, є сьогодні тим електор льним осередком у кр їні, який може ст ти основним ядром н ціон льно-демокр тичних сил.

е однією причиною пор зки претендент ст ли висловлюв ння тепер уже колишнього президент . щенк, який весь ч с з являв т ке: “ кр їнці, по суті, не м ють спр вжнього укр їнського вибору. е б чу принципової різниці між обом претендент ми. олосув ти з одного - втр тити голову. олосув ти з другого претендент - не м ти серця". щенкові слов вплинули н н строї н ціон льно-демокр тичних сил т гром дянсько-політичне об'єдн ння “ лицький вибір”, яке т кож 3 клик ло кр ян прийти 7 лютого н дільниці, одн к проголосув ти проти обох к ндид тів [4, с. 4].

роте, з клики до г лич н підтрим ти у другому турі п тріотичного к ндид т . окрем , відомий письменник . вличко ск 3 в: “ . нукович іде у президенти для того, щоб знищити укр їнську мову (мов - це перший крок), він іде, щоб знищити н ш н род. ех й би львівськ інтелігенція виступил і ск 3 л : ті, що голосують “проти всіх", голосують проти . имошенко, зн чить-з . нукович ”. іншому висловлюв нні митро сильович уточнив, що буде, якщо президентом ст не . нукович: “ кр їн , стр шно ск 3 ти, обернеться н губернію відновленої російської імперії” [7, c. $9-10]$.

дн к перші висловлюв ння були куди більш переконливими, що й д ло свої результ ти. он д 4 \% по кр їні проголосув ли проти обох к ндид тів, що є н йбільшим відсотком з всі попередні вибори. кож однією з причин пор зки п тріотичного К ндид т . имошенко, ст л низьк явк виборців порівняно з іншими вибор ми. окрем , ьвівщин 2004 р. у третьому турі відд л 1,7 млн голосів, під ч с другого туру 2010 - тільки 1,3 млн, тобто н 400 тис. голосів менше. е пішло н користь і те, 
що у ьвові 7 \% виборців проголосув ло проти обох к ндид тів, у місті иєві - $8 \%$ [10].

тже, територі льн поляриз ція електор ту н хід- хід 2010 р. зберегл ся, як і н попередніх вибор х. орівняно з іншими вибор ми, вибори 2010 р. м ли дві особливості.

1) меншу явку виборців;

2) високу ч стку голосів проти обох к ндид тів.

плив Г лицьких регіонів н результ ти виборів був не досить зн чним порівняно з іншими президентськими вибор ми, оскільки тоді перем г ли більш п тріотичні к ндид ти, з яких голосув ли г лич ни. вибор х 2010 р. перемогу здобув проросійський к ндид т, з якого г лич ни відд ли тільки $1 \%$ від з г льноукр їнського. опри те, що вплив личини дещо зменшився, особливо н результ ти виборів 2010 р., г лицький регіон м є великий потенці л н рощення електор ту, який у н йвідповід льніший момент об'єднується і д є н йвищу явку як н п рл ментських, т к і н президентських вибор х в кр їні.

1. врилюк . иборі д : другий тур / . врилюк // епортер. 2010. № 6.

2. ністрянський . . тнополітичн геогр фія кр їни : проблеми теорії, методології, пр ктики / . . ністрянський: оногр фія. ьвів : ітопис; 2006. 490 с.

3. ьюи ж. бщество и его проблемы / ж ьюи. . : дея- pecc, 2002. 160 с.

4. рпінський . “ е підтримуємо жодного” / . рпінський. // кспрес. 2010. № 10.

5. отляр . “ ві кр їни”: що з ними робити? / . отляр // зерк ло тижня. 2010. № 4.

6. иронюк . . лектор льн орг ніз ція регіону (н м тері л х лицьких обл стей) / иронюк: ис. к нд. геог. н ук. ьвів, 2002.

7. уденко . “" роти всіх” як технологія з дурні гроші / . уденко // вобод . 2010. № 10

8. н. . лектор льн геогр фія риму: / . н: ис. к нд. геогр. н ук. дес 1999.

9. ироков . . собливості кр їнської електор льної культури / . . ироков // оці льні технології. 2010. № 45.

10. http://www.zaxid.net/newsua/2010/2/14/151717/.

11. http://polityka.in.ua/info/353.htm

12. http://cvk.gov.ua

\section{THE INFLUENCE OF GALICIA REGIONS ON THE RESULTS OF ELECTION CAMPAIGN ON THE PRESIDENT OF UKRAINE 2010}

\section{A. Galchak}

Ivan Franko National University of Lviv, . Doroshenko St., 41, UA - 79000 Lviv, Ukraine

It was analyzed the campaign procedure of the national "presidential election in Ukraine". The analysis of the differences of the regions under the influence of different factors was made. The features of election in 2010 was showed on the back ground of another election. It is defined the influence of Galicia regions on the results of election in 2010.

Key words: presidential election, Galicia, an electoral behavior, the results of election, national democratik candidate. 
2010

\section{- ЛЬч $\mathbf{K}$}

ьвовский н иион льный университет имени в н ул. . орошенко, 41, г. ввов, 79000, кр ин

скрыто сущность понятия “выборы президент кр ины”. дел н н лиз отличий регионов стр ны под воздействием р зных ф кторов. тобр жены особенности выборов 2010 г. н фоне других выборов. пределено влияние лицкого регион н результ ты выборов 2010 г.

лючевые слов : выборы президент , лиция, электор льное поведение, результ ты выборов, п триотический к ндид $\mathrm{T}$.

т ття н дійшл до редколегії 10.02.2011 рийнят до друку 19.04.2011 